\title{
Desempeño de la gestión competitiva en agroindustrias: estudio de casos lácteos de La Pampa
}

Performance of Competitive Management in Agroindustries: a Study of Dairy Cases from La Pampa

Desempenho da gestão competitiva em agroindústrias: um estudo de casos de laticínios de La Pampa

Rocío Lujan González UNLPam, La Pampa, Argentina E-mail:rgonzalez@agro.unlpam.edu.ar

Santiago Agustín Perez CONICET, La Pampa, Argentina E-mail: santiagoagusperez@gmail.com

\author{
Roberto Carlos Mariano \\ UNLPam, La Pampa, Argentina \\ E-mail:rcmariano@agro.unlpam.edu.ar \\ Santiago Ferro Moreno \\ UNLPam, La Pampa, Argentina \\ E-mail: sferromoreno@agro.unlpam.edu.ar
}

Fecha de Recepción: 11/06/2021 Fecha de Aceptación: 30/09/2021

Palabras clave - entramado agroindustrial - gestión agroindustrial

- índice competitivo

- planeación estratégica

- ventajas competitivas

\section{Resumen}

El objetivo del trabajo es evaluar los factores que potencian 0 condicionan la competitividad del complejo agroindustrial lácteo de primera transformación de la provincia de La Pampa. El complejo está conformado por un total de 21 agroindustrias habilitadas, de las cuales se entrevistó a 14. A partir del análisis de antecedentes y marco teórico, se identificaron 9 ejes y 67 indicadores para la medición del desempeño competitivo. A partir de estos indicadores, se analiza el comportamiento de estos factores a nivel agroindustrial y luego a nivel del complejo lácteo (14 organizaciones). Con estos resultados, se determina el índice de desempeño competitivo del complejo agroindustrial lácteo pampeano, representando una competitividad baja. El complejo agroindustrial lácteo se apalanca positivamente en la gestión estratégica y económica productiva, y traccionan negativamente los ejes relacionados a la gestión ambiental y comercial. Teniendo en cuenta los ejes de competitividad, se agruparon las agroindustrias en cuatro conglomerados diferentes, conformados por el desempeño en los ejes competitivos. Las agroindus- 
Keywords - agro-industrial management

- agro-industrial entry

- competitive index

- competitive advantages

- strategic planning trias que conforman los cuatro conglomerados se relacionan según la positividad o negatividad de sus índices competitivos. Los factores que potencian la competitividad son la satisfacción del cliente, saber hacer, financiamiento con capital propio, imagen, precio, preparación y formación del personal, e innovación de procesos. Los que restringen competitividad son la satisfacción de clientes, descarte de residuos, planes de pago y moratorias y aprovisionamiento de insumos. La metodología propuesta permite medir y evaluar distintas aristas de la competitividad en cada organización y de los complejos agroindustriales en general.

\section{Abstract}

The aim of this work is to evaluate the factors that enhance or condition the competitiveness of the first transformation dairy agro-industrial complex in the province of La Pampa. The complex is made up of a total of 21 authorized agro-industries, of which 14 were interviewed. From the analysis of the background and the theoretical framework, 9 axes and 67 indicators were identified to measure competitive performance. Based on these indicators, the behaviour of these factors at the agro-industrial level and then at the dairy complex level (14 organizations) is analyzed. With these results, the competitive performance index of the Pampean agro-industrial complex is determined: it represents low competitiveness. The strengths of the agroindustrial complex include strategic and productive economic management, and its weaknesses are related to environmental and commercial management. Taking into account the competitiveness axes, the agroindustries were grouped into four different conglomerates, according to their performance in the competitive axes. The agroindustries that make up the four clusters are related according to the positivity or negativity of their competitive indices. The factors that enhance competitiveness are customer satisfaction, knowhow, financing with own capital, image, price, preparation and training of personnel and process innovation; while those that restrict competitiveness are customer satisfaction, waste disposal, payment plans and moratoriums and supply of inputs. The proposed methodology allows to measure and evaluate different edges of the competitiveness of each case and of the agro-industrial complex in general.

\section{Resumo}

0 objetivo do trabalho é avaliar os fatores que potencializam ou condicionam a competitividade do primeiro complexo agroindustrial de transformação de laticínios da província de La Pampa. 0 complexo é formado por um total de 21 agroindústrias credenciadas, das quais 14 foram entrevistadas. A partir da análise de histórico e marco teórico, foram identificados 9 eixos e 67 indicadores para medir o desempenho competitivo. Com base 
Palavras-chave

- índice de competitividade

- gestão agroindustrial

- planejamento estratégico tecido agroindustrial

- vantagens competitivas nesses indicadores, analisa-se o comportamento desses fatores no nível agroindustrial e depois no nível do complexo leiteiro (14 organizações). Com esses resultados, é determinado o índice de desempenho competitivo do complexo agroindustrial pampeano, que representa baixa competitividade. 0 complexo agroindustrial é positivamente alavancado na gestão econômica e estratégico-produtiva e puxa negativamente os eixos relacionados à gestão ambiental e comercial. Levando em consideração os eixos de competitividade, as agroindústrias foram agrupadas em quatro conglomerados distintos, compostos pela atuação nos eixos competitivos. As agroindústrias que compõem os quatro clusters relacionam-se de acordo com a positividade ou negatividade de seus índices de competitividade. 0 s fatores que aumentam essa competitividade são a satisfação do cliente, know how, financiamento com capital próprio, imagem, preço, preparação e formação de pessoal e inovação de processos, e os que a restringem são a satisfação do cliente, descarte de resíduos, planos de pagamento e moratórias e abastecimento de insumos. A metodologia proposta permite medir e avaliar diferentes facetas da competitividade de cada caso e do complexo agroindustrial em geral. 